\title{
開水路凹部における流れの 組織運動の二次元ウェーブレット解析 \\ TWO-DIMENSIONAL WAVELET ANALYSIS ON ORGANIZED MOTION IN OPEN-CHANNEL FLOW OVER CONCAVE BED
}

\author{
宮本仁志 1 ・神田 徹 2 \\ Hitoshi MIYAMOTO and Tohru KANDA \\ 1正会員 修士(工学) 神戸大学助手 工学部建設学科（†657-8501 神戸市灘区六甲台町1-1） \\ 2 フェロー会員 工博 神戸大学教授 工学部建設学科（同 上）
}

\begin{abstract}
Turbulent structures along a mixing layer in an open-channel flow over a concave bed are analyzed using wavelet transforms. Experimental data of the velocity are obtained by a particle image velocimetry (PIV). At first, we evaluate the accuracy of the PIV velocity data by employing a multiresolutional analysis (MRA). The result of MRA shows that the instantaneous Reynolds stress is an appropriate signal for the coherent structure detection. Then, the distributions of the instantaneous Reynolds stress are analyzed using a two-dimensional continuous wavelet transform (2D-CWT). The spatial scales and locations of the coherent structures are detected from the maximal values of the wavelet coefficients. The characteristics of the organized motions along the mixing layer, such as an evolution of spatial scale, advection velocity, and occurrence interval, are clearly extracted in terms of the location and the time.
\end{abstract}

Key Words : wavelet analysis, open-channel, concave bed, turbulent mixing layer, coherent structure, particle image velocimetry

\section{1. はしがき}

近年，河川環境への意識の高まりから，瀬や淵，わん ど等のように自然生態系との共生を考慮した河道設計を 行うことが重要となっている.このような断面急変部で は一次元解析では不十分であるだけでなく, 二次元・三 次元的取扱いにおいても流れの非定常挙動を詳細に把握 する必要がある. 計測手法の発達によって種々の乱流構 造が明らかにされつつあるが，その非定常特性は断面形 状や水理条件によって大きく変化するので，流れの計測 手法をさらに改善させると同時に, 複雑な乱流構造を解 明するための新たな解析方法の導入も重要である.

本研究はそのような河道局所変化部における流れの挙 動解明を目標として, これまで, 水路床に凹部をもつ開 水路(以下, 開水路凹部)の流れについてPIV(particle image velocimetry)で得られる流速場を解析し，その流況特性を 調べてきた(1)-3). 前報1), 2)では, 一次元ウェーブレット理 論を用いて主流一凹部境界のせん断混合層(以下，凹部 混合層)における流れの組織運動を解析し，凹部形状の
違いによる組織運動の挙動変化を考究するとともに, 乱 流組織運動に対する同変換の有効性を確認した.

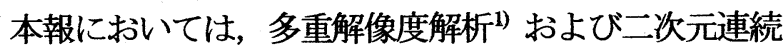
ウェーブレット変換"を用いることにより，凹部混合層 における乱流構造の条件抽出を行い, 組織運動の空間ス ケール，走時挙動などの流況特性を調べる. また, 得ら れた結果より，流れの組織運動の解析に対するウェーブ レット理論の適用性を検討する.

流れの組織運動の解析手法としては, 四象限分類法, VITA 法 (variable interval time averaging), POD(proper orthogonal decomposition)などが従来用いられている. Liandrat とMoret-Bailly) は, VITA法とウェーブレット変 換の能力比較を行い, 信号の多重スケール分解が可能で あるウェーブレット変換の優位性を示している. また, PODは，変動成分の空間相関マトリックスの固有値を用 いて主成分分析を行う統計的手法であり，直接，信号を 対象とするウェーブレット解析とは本質的に異なる手法 である. 著者らは，このPODを用いることにより，開水 路凹部流れにおける主要な流速変動成分の解析を行って いる6). 


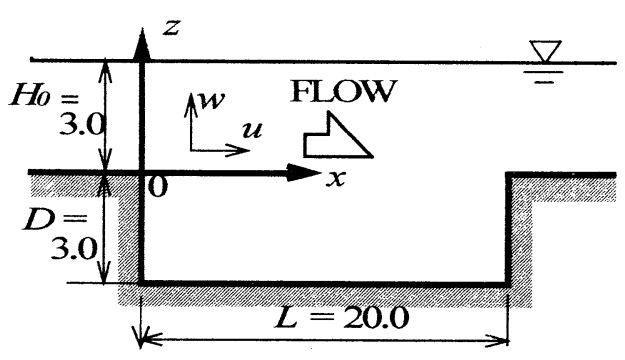

図-1 開水路凹部の模式図

表-1 実験条件

\begin{tabular}{|c|c|}
\hline 流量 : $Q\left(\mathrm{~cm}^{3} / \mathrm{sec}\right)$ & 758 \\
\hline 流入水深 : $H_{0}(\mathrm{~cm})$ & 3.0 \\
\hline 流入部での断面平圴流速 : $U_{0}(\mathrm{~cm} / \mathrm{sec})$ & 12.6 \\
\hline Reynolds 数 : $R e=U_{0} H_{0} / \nu$ & 3800 \\
\hline Froude 数 : $F r=U_{0} /\left(g H_{0}\right)^{1 / 2}$ & 0.23 \\
\hline 凹部形状比 : $L / D$ & 6.7 \\
\hline
\end{tabular}

\section{2. 実験の概要}

\section{（1）開水路凹部および実験条件}

図一に，本研究で用いた穾験水路の模式図を示す．実 験水路は，全長 $500 \mathrm{~cm} ，$ 幅 $20 \mathrm{~cm}$ のアクリル製水路であり， 上流水槽より $330 \mathrm{~cm}$ の位置に凹部を設けている. PIV計 測では, 比重 1.02 , 粒径0.075 0.15mmの高分子ポリ マー粒子をトレーサーとして流水中に投入し，スリット 状にしたヘリウム・ネオンレーザー光を照射することに よって可視化断面を作成した. 得られた可視化画像を濃 淡画像相関法(PIV $\left.{ }^{3}\right)$ によって解析し, 断面内の流速分布 を得た. なお，流速べクトル算出の際には，粒子のサブ ピクセル内移動に対する補間および異常流速べクトルの 検出・補間の処理を行っている. PIVの計測断面は凹部 の鉛直中央である．画像のサンプリング周波数(時間分 解能) は $60 \mathrm{~Hz}$ ，可視化画像の空間分解能 (1pixel) は約 0.42mmであり，約33秒間(2000画像) の面的な流速べク トルを解析対象とする．表-1に実験条件を示す。

\section{（2）時間平均流速}

図-2に，時間平均流速ベクトルを示す，対象とする流 れ場は, レイノルズ数 $R e=3800$, フルード数 $F r=0.23$ で，水面変動が無視できる流れである．主流一几部境界 で流速せん断が大きく，流下方向にせん断混合層が発達

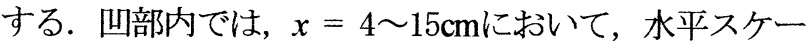
ルが約 $8 \mathrm{~cm}$ ，鉛直入ケールがほぼ凹部深さDに等しい循 環流が存在しており，その下流側の隅角部に規模の小さ い循環流が，上流側には微小流速の死水域が形成されて いる. 本研究では，この凹部混合層内での流れの組織的 構造に焦点をあてる.

\section{3. ウェーブレット変換の概要}

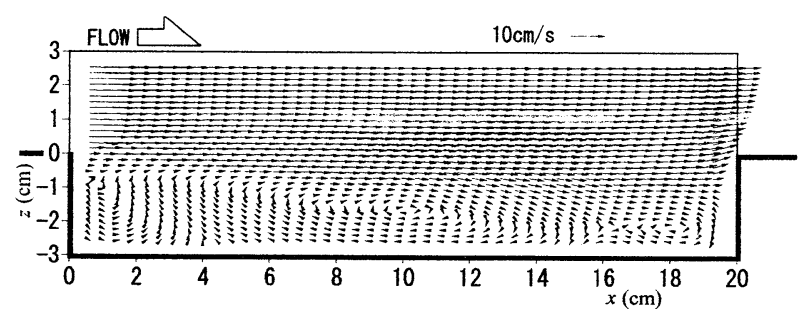

図-2 時間平均流速ベクトル

本研究においては, 多重解像度解析では流速時系列を, 二次元連続ウェーブレット変換では瞬間レイノルズ応力 の空間分布 (後述)を解析対象とするので，それぞれ時間 $t$, 位置ベクトル $\boldsymbol{X}=(x, z)$ を独立変数として説明を行う.

\section{（1）多重解像度解析}

多重解像度解析は，離散ウェーブレット変換に用いる 正規直交ウェーブレットとそれに対応するスケーリング 関数を用いて, 解析対象とする関数 $f(t)$ をそれら基底 関数で構成される空間に展開する.

$f(t)$ の離散ウェーブレット変換は次式で定義される.

$$
\tilde{f}_{\mathrm{ji}}=\left\langle\psi_{\mathrm{ji}} \mid f\right\rangle=\int_{-\infty}^{\infty} f(t) \psi_{\mathrm{ji}} \mathrm{d} t
$$

ここに,

$$
\begin{aligned}
& \psi_{\mathrm{ji}}=2^{\mathrm{j} / 2} \psi\left(2^{\mathrm{j}} t-\mathrm{i}\right) \\
& \langle\psi(t) \mid \psi(t-\mathrm{n})\rangle=\int_{-\infty}^{\infty} \psi(t) \psi(t-\mathrm{n}) \mathrm{d} t=\delta_{\mathrm{n}, 0}
\end{aligned}
$$

$\psi_{\mathrm{ji}}$ : 正規直交ウェーブレット, $\widetilde{f}_{\mathrm{ji}}$ : 離散変換によって 得られるウェーブレット係数, $\delta$ : クロネッカーデルタ, $\mathrm{i}, \mathrm{j}, \mathrm{n}$ : 任意の整数である. 式(2)，(3)より， $\psi_{\mathrm{ji}}$ は $t$ 軸 上の離散移動 $2^{-\mathrm{j}} \mathrm{i}$ に対して直交する関数となる.

多重解像度解析は次式で示される。

$$
f(t)=\sum_{\mathrm{i}=-\infty}^{\infty}\left\langle\phi_{\mathrm{mi}} \mid f\right\rangle \phi_{\mathrm{mi}}(t)+\sum_{\mathrm{j}=\mathrm{m}}^{-1} \sum_{\mathrm{i}=-\infty}^{\infty}\left\langle\psi_{\mathrm{ji}} \mid f\right\rangle \psi_{\mathrm{ji}}(t)
$$

ここに

$$
\begin{gathered}
\phi_{\mathrm{ji}}(t)=2^{\mathrm{j} / 2} \phi\left(2^{\mathrm{j}} t-\mathrm{i}\right), \quad \int_{-\infty}^{\infty} \phi(t) \mathrm{d} t=1 \\
\langle\phi(t) \mid \phi(t-\mathrm{n})\rangle=\int_{-\infty}^{\infty} \phi(t) \phi(t-\mathrm{n}) \mathrm{d} t=\delta_{\mathrm{n}, 0} \\
\langle\phi(t) \mid \psi(t-\mathrm{n})\rangle=\int_{-\infty}^{\infty} \phi(t) \psi(t-\mathrm{n}) \mathrm{d} t=0
\end{gathered}
$$

上式の $\phi$ はスケーリング関数である. 式(5)の $\phi_{\mathrm{ji}}$ は, 式 (6), (7)に示すように $\phi_{\mathrm{ji}}$ および $\psi_{\mathrm{ji}}$ の離散移動 $2^{-j} \mathrm{i}$ に対 して直交する関数である. $\psi_{\mathrm{ji}}, \phi_{\mathrm{ji}}$ 考周波数帯域分割 フィルターと考えれば，前者は周波数帯を二分割する八 イパスフィルター, 後者はローパスフィルターとなる. したがって, 式(4)は，それらのフィルターを用いて $f(t)$ を各周波数帯の階層構造に展開したものと考えて よい. また，正規直交関数を用いて関数 $f(t)$ を展開し ているため, $f(t)$ は, 得られた各周波数帯での関数と 対応するウェーブレット係数を用いて再合成できる. な 


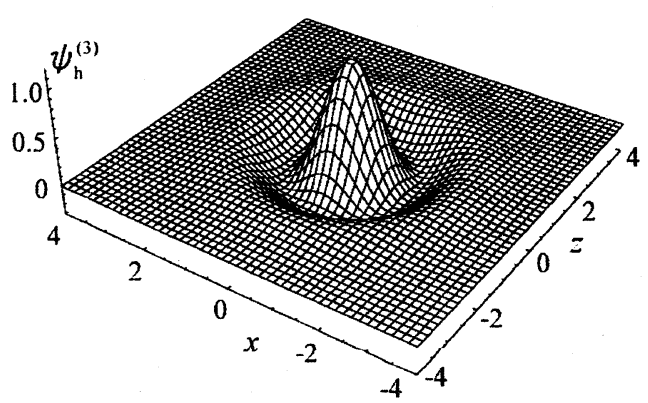

図-3 マザーウェーブレット（二次元）

(ガウス分布の高次オーダーラプラシアン $(\mathrm{n}=3)$ )

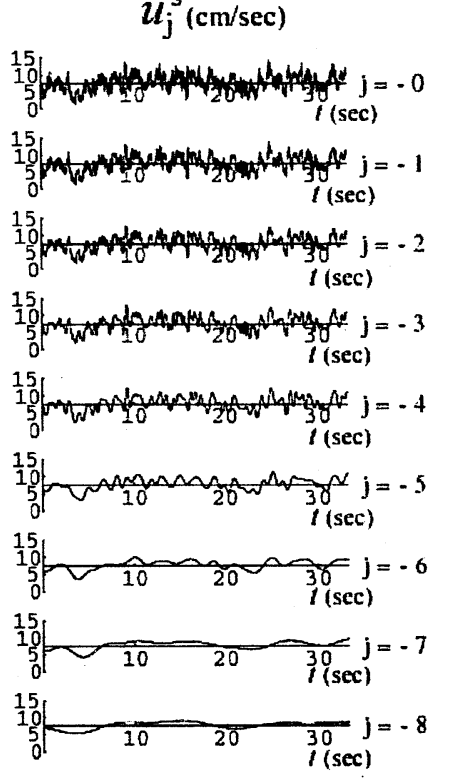

（a） $x$-方向流速 $u$ の多重解像度解析

\begin{tabular}{|c|c|c|}
\hline $\begin{array}{c}\text { レベル } \\
j\end{array}$ & $\begin{array}{c}\text { 近似流速成分 } \\
u_{\mathrm{j}}^{\mathrm{s}}, w_{\mathrm{j}}^{\mathrm{s}}\end{array}$ & $\begin{array}{c}\text { 変動流速成分 } \\
u_{\mathrm{j}}{ }^{\mathrm{W}}, w_{\mathrm{j}}^{\mathrm{W}}\end{array}$ \\
\hline 0 & 30Hz以下 & \\
\hline-1 & 15Hz以下 & $15 \sim 30 \mathrm{~Hz}$ \\
\hline-2 & $7.5 \mathrm{~Hz}$ 以下 & $7.5 \sim 15 \mathrm{~Hz}$ \\
\hline-3 & 3.8Hz以下 & $3.8 \sim 7.5 \mathrm{~Hz}$ \\
\hline-4 & 1.9Hz以下 & $1.9 \sim 3.8 \mathrm{~Hz}$ \\
\hline-5 & $0.9 \mathrm{~Hz}$ 以下 & $0.9 \sim 1.9 \mathrm{~Hz}$ \\
\hline-6 & $0.5 \mathrm{~Hz}$ 以下 & $0.5 \sim 0.9 \mathrm{~Hz}$ \\
\hline-7 & $0.2 \mathrm{~Hz}$ 以下 & $0.2 \sim 0.5 \mathrm{~Hz}$ \\
\hline-8 & $0.1 \mathrm{~Hz}$ 以下 & $0.1 \sim 0.2 \mathrm{~Hz}$ \\
\hline
\end{tabular}

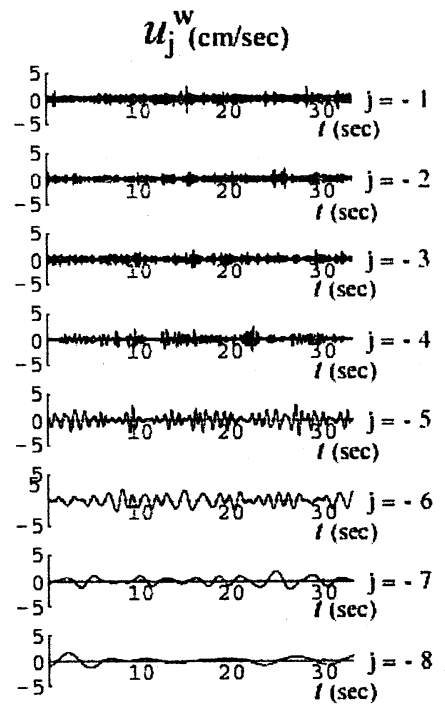

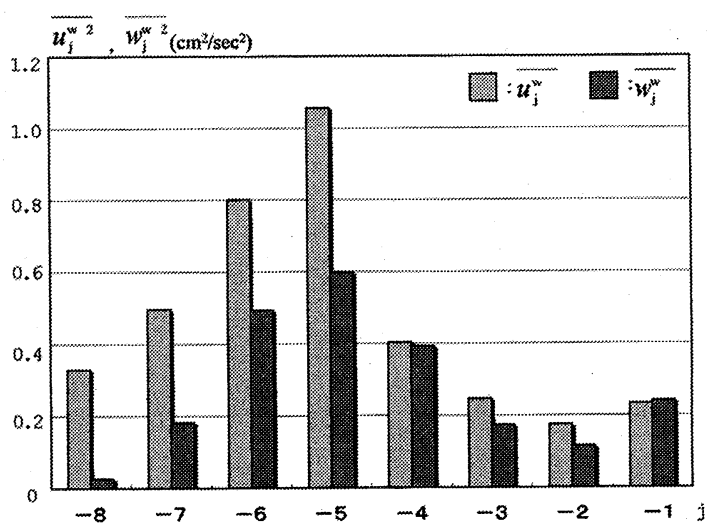

(b) 各レベルにおける流速成分の変動強度

図-4 多重解像度解析の結果 $(x=10.36 \mathrm{~cm}, z=-0.01 \mathrm{~cm})$

お, 本研究では, Daubechiesの正規直交ウェーブレット ${ }_{\mathrm{N}} \psi$ およびスケーリング関数 ${ }_{\mathrm{N}} \phi \quad(\mathrm{N}=10)^{7)}$ を基底関数 として用いた.

\section{（2）二次元連続ウェーブレット変換}

関数 $f(\boldsymbol{x})=f(x, z)$ の二次元連続ウェーブレット変換 は次式で定義される.

$$
\begin{aligned}
W[f]=\widetilde{f}\left(l, \boldsymbol{x}^{\prime}\right) & =\left\langle\psi_{l, \theta, \mathbf{x}^{\prime}} \mid f\right\rangle \\
= & l^{-2} \int \overline{\psi\left(l^{-1} r_{-\theta}\left(\boldsymbol{x}-\boldsymbol{x}^{\prime}\right)\right)} f(\boldsymbol{x}) \mathrm{d} \boldsymbol{x}
\end{aligned}
$$

ここに, $\tilde{f}\left(l, \boldsymbol{x}^{\prime}\right)$ : ウェーブレット倸数, $l, \boldsymbol{x}^{\prime}, r_{-\theta}$ : それぞれウェーブレットの幅，位置，および方向に対応 するスケールパラメータ, 移動パラメータ, 回転マト リックス, $\bar{\psi}$ : 関数 $\psi$ の複素共役である. なお, 式(8) の $l^{-2}$ は, ウェーブレット係数を規準化するための係数 であり,ここでは，関数 $f(\boldsymbol{x})$ のスケールを抽出するの でL1ノルムで規準化している. 各パラメータを変化させ ることによりマザーウェーブレット $\psi$ を拡大・縮小， 移動および回転させ， $\psi_{l, \theta, \mathbf{x}^{\prime}}$ と $f$ との内積により関数
の局所的な変動特性を抽出する. 本研究では, 次式で表 される, ガウス分布の高次オーダーラプラシアン $(\mathrm{n}=$ 3）をマザーウェーブレットとして用いた.

$$
\psi_{\mathrm{h}}^{(\mathrm{n})}(\boldsymbol{x})=(-\Delta)^{\mathrm{n}} \exp \left(-|x|^{2} / 2\right)
$$

図-3に，マザーウェーブレット $\psi_{\mathrm{h}}^{(3)}(x, z)$ を示す。 なお， 本研究で用いたウェーブレットは等方性ウェーブレット であるため，式(8)における回転マトリックス $r_{-\theta}$ はパ ラメータから除かれる。

\section{4. 解析結果と考察}

\section{（1）多重解像度解析による変動流速成分の抽出}

PIV 計測で得られた各点 $(x, z)$ の流速時系列 $v$ $(x, z, t)(=u(x, z, t), w(x, z, t))$ に多重解像度解析 ${ }^{1)}$ を適用 することにより, 流れの組織運動起構成する周波数帯成 分を抽出する.

図-4(a) は，凹部中央 $(x=10.36 \mathrm{~cm}, z=-0.01 \mathrm{~cm})$ にお ける $x$-方向流速時系列 $u(x, z, t)$ に多重解像度解析を適用 


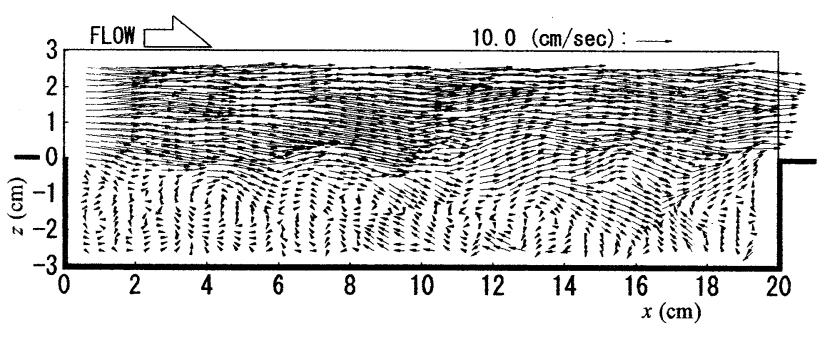

(a) 瞬間流速 $v$

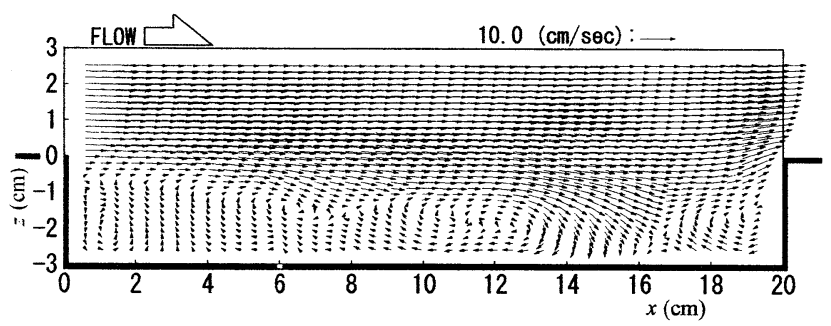

(b) 近似流速成分 $\bar{V}$

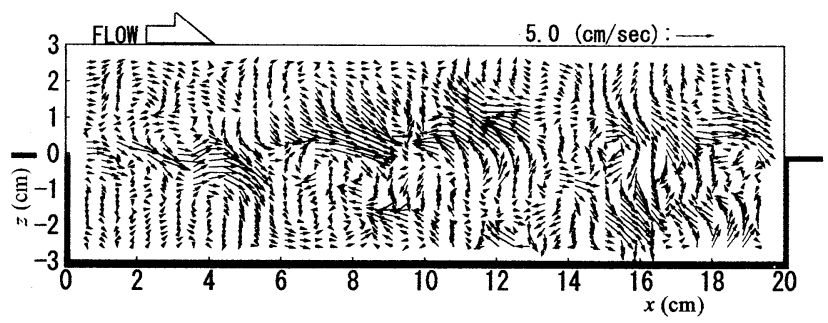

（c）変動流速成分 $\boldsymbol{V}$ ，

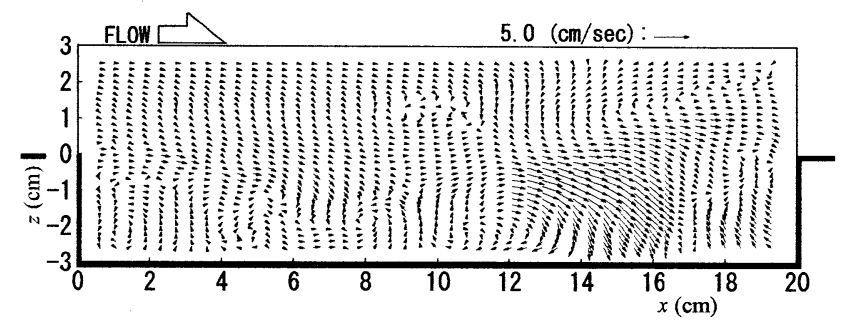

(d) 時間平均流速と近似流速成分の残差 $V-\overline{\boldsymbol{V}}$

図-5 各周波数帯に分解された流速べクトル

することにより各周波数帯 (レベルj) での近似流速成分 $u_{\mathrm{j}}^{\mathrm{s}}(t)$ と変動流速成分 $u_{\mathrm{j}}^{\mathrm{w}}(t)$ に分解した各時系列であり, 図-4(b) は, 同一点におけるレベルj の変動強度 $\overline{u_{\mathrm{j}}^{\mathrm{w}}}$, $\overline{w_{\mathrm{j}}^{\mathrm{w}}}$ の分布である. 表-2に各レベルjの周波数帯を示す. 図-4(a)より，レベルj が小さくなるとともに高周波数 の変動流速成分 $u_{\mathrm{j}-1}{ }^{\mathrm{w}}(t)$ が近似流速成分 $u_{\mathrm{j}}^{\mathrm{s}}(t)$ から分離さ れ，時系列の変動が段階的に除去されていくのがわかる. 図-4(b)に示寸 $\overline{u_{\mathrm{j}}^{\mathrm{w}}}, \overline{w_{\mathrm{j}}^{\mathrm{w}}}$ は, レベルj $=-5(0.9 \sim 1.9 \mathrm{~Hz})$ でじちらも最大となる．また， $\overline{u_{\mathrm{j}}^{\mathrm{w}}}$ はそれより低周波数 域で比較的大きな值をとり， $\overline{w_{j}^{\mathrm{w}} 2}$ はレベル $=-5$ を頂点 としてほぼ左右対称な分布となる．このことより，変動 エネルギーは低周波数域で主流から $\overline{u_{\mathrm{j}}^{\mathrm{w}}}$ 成分に供給さ れ高周波数になる゙に伴って $\overline{w_{j}^{\mathrm{w} 2}}$ に伝播されていくこと が推測でき，組織運動の最も卓越する周波数帯は0.9〜

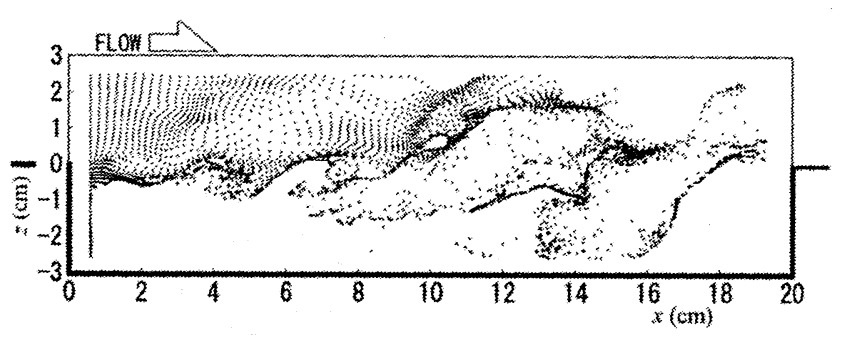

図一6擬似粒子による流脈図(図-5の時刻に対応)

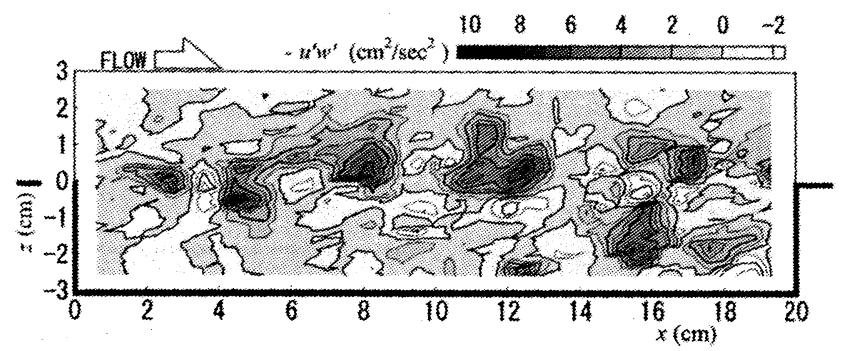

図-7 瞬間レイノルズ応力の分布(図-5の時刻に対応)

1.9Hzであると考学られる．また，レベルj $=-1$ での変動 強度が大きい值をとるのは, PIVの計測誤差(ノイズ)に よるものと考えられる. 以上より, 本研究では, $\overline{w_{\mathrm{j}}^{\mathrm{w}}}$ が小さい $\mathbf{j}=-8$ ，ノイズを含む $\mathbf{j}=-1$ およびその一つ上の レベルj $=-2$ を除き, 残りの周波数 $f=0.2 \sim 7.5 \mathrm{~Hz}$ の成 分を組織運動に関わる変動流速成分 $\boldsymbol{V}$, として解析を行 うことにした.

\section{（2）解析対象の信号となる瞬間レイノルズ応力の分布}

二次元連続ウェーブレット変換を適用する前に, 抽出 した変動流速成分 $\boldsymbol{V},(x, z, t)\left(=u^{\prime}(x, z, t), w^{\prime}(x, z, t)\right)$ につ いて検討を行う. 図-5に, ある時刻の瞬間流速べクトル $\boldsymbol{v}$, 低周波数域の近似流速成分 $\bar{v}$ (周波数 $f=0 \sim 0.2 \mathrm{~Hz}$ ), 変動流速成分 $\boldsymbol{V}$ ' $(f=0.2 \sim 7.5 \mathrm{~Hz})$, および $\bar{V}$ と図-2の時 間平均流速 $V(x, z, t)(=U(x, z, t), W(x, z, t))$ の残差: $V-$ $\bar{v}$ の空間分布を示す. 図-5(d)に示方残差の流速べクト ルは, 主に凹部水深 $D$ 程度のスケールをもつ低周波数の 変動成分 (近似流速のトレンド)である. 図-5(c)に示す 変動流速成分 $v$ 'の分布では, ベクトルの絶対值が大き い部分 (変動流速卓越部) が，ほぼ一定間隔で存在してい るのがわかる. 各部の変動流速べクトルはほぼ同一方向 を示しており，そのほとんどが，高速流体 $\left(u^{\prime}>0\right)$ の凹 部内一の潜り込み $\left(w^{\prime}<0\right)$, もしくは, 低速流体 $\left(u^{\prime}<0\right)$ の巻き上がり $\left(w^{\prime}>0\right)$ である.

図-6は，凹部上流断面 $(x=0.6 \mathrm{~cm}$ の鉛直線上)におい て時間間隔 $1 / 60 \sec$ で投入した擬似粒子の流脈図である (図-5の時刻に対応)。ここで, 擬似粒子の位置は, $\bar{v}(x, z, t)+v^{\prime}(x, z, t)$ を用いて算出している. 四部混合 層の縁(主流域との境および下層の微流速域との境)がよ く可視化されている. 図-5(c) で見ることができる変動 流速卓越部は，その縁に沿って存在している.

図-7は，変動流速成分 $\boldsymbol{v}$ '(図-5 (c)) から算出した瞬間 


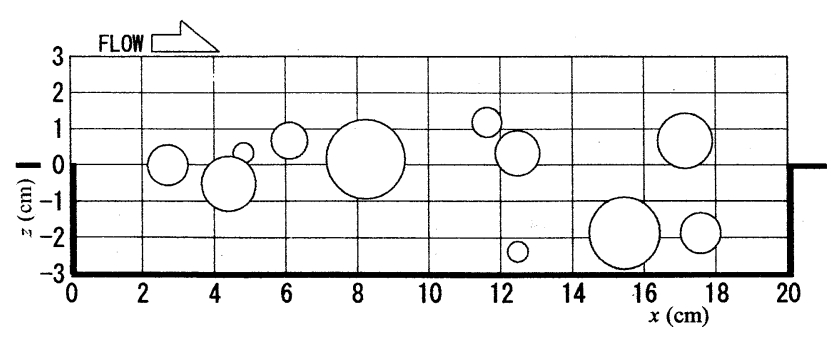

図-8 ウェーブレット係数極大值の位置と スケールの空間分布(図一7に対応)

レイノルズ応力 $-u^{\prime} w^{\prime}(x, z, t)$ の分布である. 瞬間レイノ ルズ応力の卓越する部分 (瞬間レイノルズ応力卓越部) は, 変動流速卓越部とよく一致し, 凹部混合層の縁に沿って 存在している.

以上のことより, 凹部混合層における流れの組織運動 を抽出する際に指標となる物理量として, 瞬間レイノル ズ応力 - $u^{\prime} w^{\prime}(x, z, t)$ を選び, その空間分布に対して二 次元連続ウェーブレット変換を適用することとする.

\section{（3）二次元ウェーブレット変換による瞬間レイノルズ応 カの空間スケールの抽出}

式(8)ではスケールパラメータ $l$ と移動パラメータ $\boldsymbol{x}^{\prime}=\left(x^{\prime}, z^{\prime}\right)$ を二次元空間で変化させて係数を計算する ため, 一次元解析 ${ }^{1,2)}$ に比べて計算負荷が膨大になる.

そこで, 瞬間レイノルズ応力 - $u^{\prime} w^{\prime}(x, z, t)$ の極大值近傍 のみでパラメータ $\boldsymbol{x}^{\prime}, l$ を変化させてウェーブレット 係数の分布を求め, その極大值に対応するパラメータに より 瞬間レイノルズ応力卓越部の空間スケール $l_{\text {max }}$ よびその位置 $\left(x_{\text {max }}, z_{\text {max }}\right)$ を抽出した.

図-8に解析結果を示す (図-7に対応)。図中における円 の直径と中心位置が，それぞれ瞬間レイノルズ応力卓越 部の空間スケール $l_{\text {max }}$ と位置 $\left(x_{\text {max }}, z_{\text {max }}\right)$ に対応する. これより, ウェーブレット係数極大值を介して, 凹部に 存在する組織運動(瞬間レイノルズ応力卓越部)の空間ス ケールを抽出できることがわかる.

\section{（4）瞬間レイノルズ応カと空間スケールの関係}

各時刻で抽出された瞬間レイノルズ応力卓越部の位置 $\left(x_{\text {max }}, z_{\text {max }}\right)$ と空間スケール $l_{\text {max }}$ を用いて, その範囲内 の瞬間レイノルズ応力 $-u^{\prime} w^{\prime}(x, z, t)$ の空間平均值 - $u^{\prime} w^{\prime}$ を算出し, 各空間スケール $($ 間隔 $\Delta l$ )ごとにその 統計平均 $-\overline{\boldsymbol{u}^{\top} \boldsymbol{w}^{\prime}}$ を次式より計算した.

$$
-\overline{u^{\prime} w^{\prime}}=\frac{1}{\mathrm{~N}_{l}} \sum \frac{4}{\pi l_{\max }^{2}} \int\left(-u^{\prime} w^{\prime}\right) d x d z
$$

ここに, $\mathrm{N}_{l}$ は，空間スケール $($ 間隔 $\Delta l)$ に含まれる事象 の数であり, 積分領域 $\mathrm{c}$ は, $\left(x_{\text {max }}, Z_{\text {max }}, l_{\text {max }}\right)$ で指定 される領域のみの積分であることを示す。

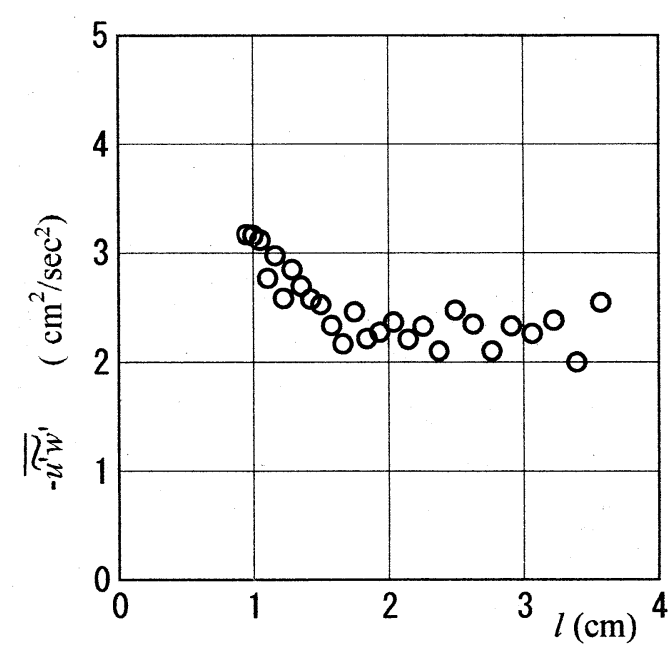

図-9 卓越領域の瞬間レイノルズ応力の平均 值と空間スケールの関係

図-9に, $-\overline{\boldsymbol{u}^{\top} \boldsymbol{w}^{\prime}}$ と空間スケールl の関係を示寸. $l$ $=1.6 \sim 1.7 \mathrm{~cm}$ を境として, 小さい空間スケールの場合， 瞬間レイノルズ応力の平均 $-\overline{\boldsymbol{u}^{\top} \boldsymbol{w}^{\prime}}$ が大きい值を示し, 空間スケールが大きくなるに従い， $-\overline{u^{\top} w_{c}^{\prime}}$ は減少して 一定値に漸近している.

\section{（5）凹部混合層における組織運動の走時挙動}

図-10は，ウェーブレット係数極大值の中心位置 $x_{\text {max }}$ と対応する時刻 $t$ の関係を, 上述の閾值 $(l=1.7 \mathrm{~cm})$ を 境にしたスケール別に示している $(-1.0 \mathrm{~cm}<z<1.0 \mathrm{~cm})$. 図中のシンボルは，対応する空間スケール $l_{\text {max }}$ を表して いる. 図-10(a)より，大きな空間スケールをもつ瞬間レ イノルズ応力卓越部は，時間の経過とともに，その空間 スケールを変化させながら流下方向に移動している. $x$ - $t$ 平面におけるこれらの帯状に連なるプロットは, 凹部 混合層での組織運動の走時挙動を反映するものと考えら れる. すなわち，これら帯の勾配は組織構造の移流速度 を, $x-, t$-方向の帯の間隔が空間的・時間的な発生間隔 をそれぞれ表している. 図-10(b)の小スケールの場合， ウェーブレット係数極大值の連続性(プロットの帯状の 連なり)は，図-10（a）の大スケールの場合ほど明瞭では ない. しかしながら, 小スケールのプロットは大スケー ルの帯の近傍に散在しており，これら二つのスケール間 に何らかの関連性があることを示唆している.

\section{5. 結 論}

本研究で得られた結果を以下にまとめて記す.

1) 開水路凹部流れのPIV流速值に対して多重解像度解析 を行い，低周波数帯でのトレンドと高周波数帯でのノ 

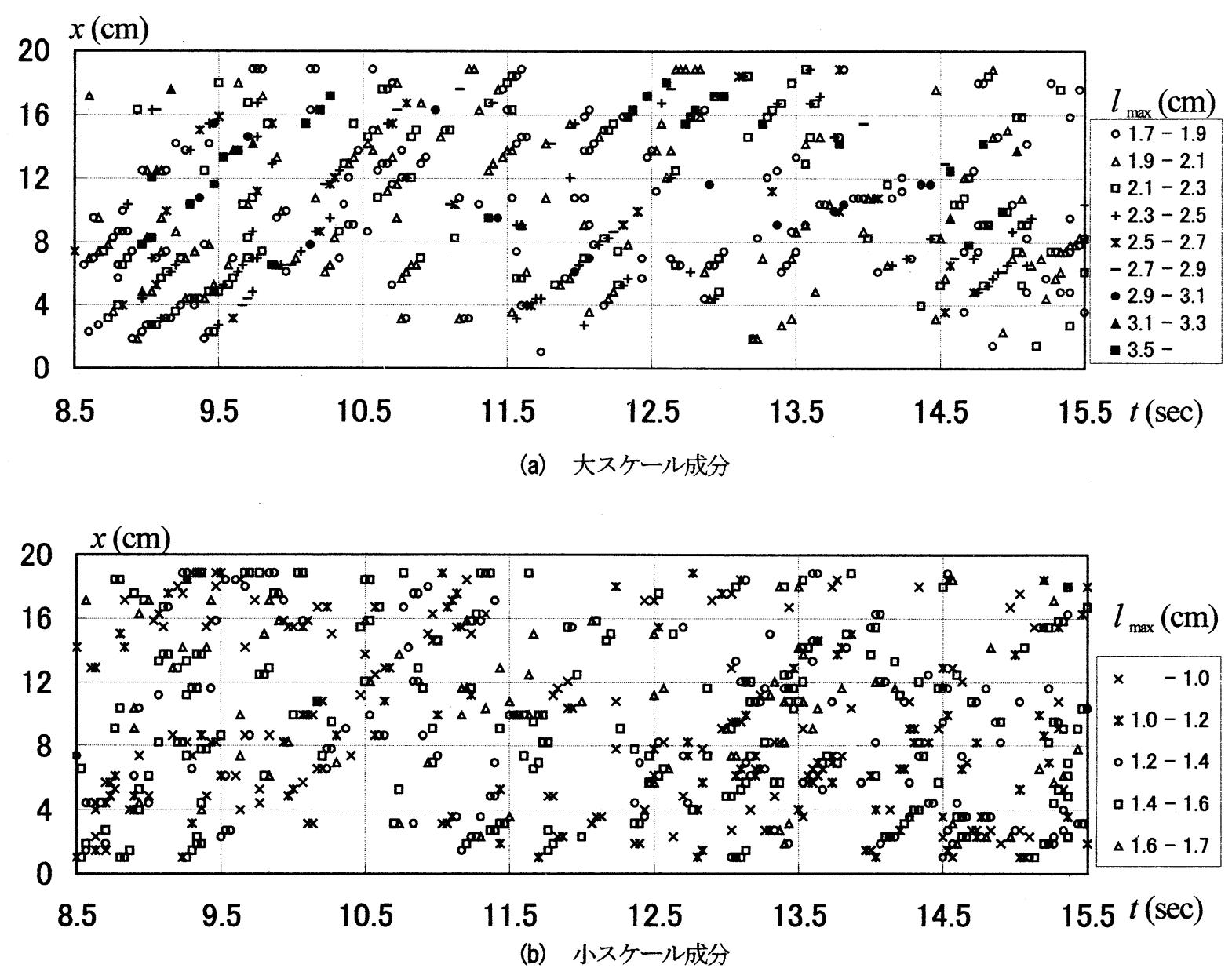

図-10 時空間平面上のウェーブレット係数極大值の分布

イズを除去し, 流れの組織運動を構成する変動流速成 分を抽出した. 多重解像度解析は, このように, 対象 となるスケール(周波数)の変動成分のみを解析するの に有効な手法である.

2) 凹部内において変動流速が卓越する部分は凹部混合層 の縁に沿って存在し、瞬間レイノルズ応力の卓越部分 と殆ど一致する. このことより, 瞬間レイノルズ応力 の空間分布を, 四部混合層における流れの組織運動を 抽出するための水理指標とした。

3) 二次元連続ウェーブレット変換を瞬間レイノルズ応力 の空間分布に適用してウェーブレット倸数を算出し， その極大值を介して瞬間レイノルズ応力卓越部の空間 スケールおよび位置を求めた.

4) 瞬間レイノルズ応力の卓越部は，その空間スケールに よって四部内での挙動が異なり, 大きなスケールの卓 越部はその空間スケールを変化させながら流下方向に 移流する.このことより，時間一空間平面における大 スケールの卓越部の分布は, 凹部混合層の組織運動の 走時挙動を反映していると考えられる.

謝辞 : 本研究は, 文部省科学研究費補助金, 奨励研究 (A) (課題番号 : 11750458, 研究代表者 : 宮本仁志)の補 助を受けた.ここに記して謝意を表します.

\section{参考文献}

1) 神田 徹, 宮本仁志, 槙野 渉: 開水路凹部のせん断混合層 におけける乱流構造のウェーブレット解析, 土木学会論文集, No.656/II-52, pp.121-133, 2000.

2) 神田 徹, 宮本仁志：ウェーブレット变換を用いた開水路凹 部流れの組織運動の解析, 水工学論文集, 第11巻, pp.515$520,2000$.

3) 宮本仁志, 神田 徹, 藤田一郎, 池上 迅 : PIVによる開水 路凹部流れの計測およひ数值解析, 水工学論文集, 第 41 巻, pp.1049-1054, 1997.

4) 例えば, Antoine, J. -P.: The 2-D wavelet transform, physical applications and generalizations, Wavelets in physics, ed. J. C. van den Berg, pp.23-75. Cambridge University Press, 1999.

5) Liandrat, J. and Moret-Bailly, F.: The wavelet transform - some applications to fluid dynamics and turbulence, Eur. J. Mech., B/Fluids, Vol. 9, No. 1, pp. 1-19, 1990.

6) 宮本仁志, 神田 徹, 兵頭伸幸: 開水路凹部流れにおける乱 れの主成分分析, 水工学論文集, 第45巻 (発表予定), 2001.

7) Daubechies, I.: Ten lectures on wavelets, CBMS Lecture Notes Series, SIAM, 1991.

(2000.10.2受付) 